\title{
A PARTY'S RECALL RIGHT IN THE CONCEPT OF DEMOCRATIC COUNTRY
}

\author{
Shevierra Danmadiyah, Xavier Nugraha, Sayyidatul Insiyah, Sayyidatul Insiyah \\ Universitas Airlangga \\ Jl. Airlangga No.4 - 6, Airlangga, Kec. Gubeng, Kota SBY, \\ Jawa Timur60115 e-mail: shevierrad.sd@gmail.com
}

\begin{abstract}
Abstrct: Elections, including the election of legislative members, especially for the House of People's Representatives and Assembly at Provincial are elected by political parties which have a big role in determining who will represent the party in parliamentary seats. It is correlated to the right of recall. In this study, researchers formulated two research problems: 1) How is the existence of a party's recall right regarding to the concept of a democratic state? and 2) How is the implementation of recall right for a party in Indonesia? This research was conducted by normative research, using a statute, conceptual, and case approach. This study found that the recall right was inappropriate to the concept of a democratic state. Even though the right of recall was the authority of a political party, it was opposed to the constituents that have given the legitimacy for the party member to be the member of the parliaments.
\end{abstract}

Keywords: recall right, political party, election, democracy.

Abstrak: Pemilihan Umum, termasuk pemilihan anggota legislatif, terutama untuk Dewan Perwakilan Rakyat dan Majelis di Provinsi dipilih oleh partai politik yang memiliki peran besar dalam menentukan siapa yang akan mewakili partai di kursi parlemen. Ini berkorelasi dengan hak mengingat. Dalam penelitian ini, peneliti merumuskan dua masalah penelitian: 1) Bagaimana keberadaan hak recall suatu partai mengenai konsep negara demokratis? dan 2) Bagaimana penerapan hak recall untuk pesta di Indonesia? Penelitian ini dilakukan dengan penelitian normatif, menggunakan pendekatan statuta, konseptual, dan kasus. Studi ini menemukan bahwa hak recall tidak sesuai dengan konsep negara demokratis. Meskipun hak untuk mengingat adalah wewenang partai politik, itu bertentangan dengan konstituen yang telah memberikan legitimasi bagi anggota partai untuk menjadi anggota parlemen.

Kata kunci: hak recall, partai politik, pemilihan umum, demokrasi.

\section{INTRODUCTION}

As a democratic country, there are some absolute things that must be in it. Those are elections, regeneration of national leadership, judicial independence, parliamentary sovereignty, obligation to respect human rights ${ }^{1}$. Indonesia as one of the countries that claims as a democracy also has responsibilities

1 Miriam Budiardjo, Dasar-Dasar Ilmu Politik, publishing XIV, Gramedia Pustaka Utama, Jakarta, 1992, p. 60. to carry out those absolute things as a manifestation of democracy.

One manifestation of democracy in Indonesia is election. Based on Article number 28D paragraph (3) of the Constitution of the Republic of Indonesia of 1945 which states "every citizen has the same right to have the same opportunity in government". The same opportunity in the election process is reflected in the opportunity to become a participant in 
the election and actively participate as a candidate in the elections.

Mostly, the general election nominating processes are always based on political parties or a combination of political parties. Election participants can be from individuals or political parties but the priority is political parties. ${ }^{2}$

A democratic country certainly legalizes the existence of political parties as pillars of democracy or the sovereignty. A political party has a central and important role in every democratic system because it is a liaison between the government and its citizens. ${ }^{3}$ In this situation, a political party can be a vehicle for a democracy.

The existence of a party's recall right in democracy is still in speculation. There are some experts who agree and disagree to the existence of recall right in a democratic country. It is considered that democracy should involve its people in every activity, but the right of recall can put the citizens as side players. Even though, the citizens have given the party members the opportunities to sit in parliament. As a result, this fact creates a very big question, are members of the house of representatives or Assembly at Provincial representing the citizens or their organizations? ${ }^{4}$

\section{METHODOLOGY}

The researcher used law-based argumentation which focused on law argumentation case study and interpretation behind the law. ${ }^{5}$ For conducting research on legal arguments, normative or doctrinal legal

2 Sigit Pamungkas, Peribal Pemilu, Laboratorium Jurusan Ilmu Pemerintahan dan Jurusan Ilmu Pemerintahan Universitas Gadjah Mada, Yogyakarta, 2009, p. 3.

3 Jimly Asshiddiqie, Pokok-Pokok Hukum Tata Negara Indonesia Pasca Reformasi, BIP, Jakarta 2007, p. 710.

4 Farida, Rida. 2013. Mekanisme Penggantian Antar Waktu (PAW) Anggota DPR dan Implikasinya dalam Konsep Perwakilan Rakyat. Jurnal Cita Hukum. Volume I (2), p. 206.

5 M.V.Hoecke,. (2011). Legal doctrine: Which method(s) for what kind of discipline?. HART Publishing. Oxford. 16 research was used. According to Terry Hutchinson $^{6}$, doctrinal research is:

"research which provides a systematic exposition of the rules governing a particular legal category, analyses the relationship between rules, explain areas of difficulty and, perhaps, predicts future development."

According to the definition, it can be seen that normative law research or doctrinal research is done through written laws. This research was also used statute approach and conceptual approach.

Statute approach was conducted by examining all laws and regulations relating to legal issues, so the ratio legis, ontological basis and philosophical basis of regulations relating to the party's recall right could be known. ${ }^{7}$ Whereas, conceptual approach was an approach that evolved from the perspectives and doctrines in the legal sciences. ${ }^{8}$ This approach was based on an understanding of the concepts in various literature, especially related to the right of recall and democracy.

The data in this research were secondary data obtained from primary, secondary and tertiary legal materials. ${ }^{9}$ Primary legal material was material that had legal binding power, such as laws and regulations, court orders, and agreements. Secondary legal material was material that had no legal binding power, suchas conscriptions, literatutes, and journals. Tertiary legal material was a complement to primary and secondary data, such as dictionaries and encyclopedias.

Data collection technique for this research was secondary data collection, which was literature study through documentaries and

\footnotetext{
${ }^{6}$ Peter Mahmud Marzuki,Penelitian Hukum, Kencana Prenada Media Group, Jakarta, 2011, p. 32.

7 Zayanti Mandasari. (2014). Politik Hukum Pengaturan Masyarakat Hukum Adat (Studi Putusan Mahkamah Konstitusi). Jurnal Hukum IUS QUIA IUSTUM. 2(1): 231.

${ }^{8}$ Zulfadli Barus. (2014). Analisis Filosofis Tentang Peta Konseptual Penelitian Hukum Normatif Dan Penelitian Hukum Sosiologis. Jurnal Dinamika Hukum. 13(2): 313.

${ }^{9}$ Faghlaifi Naim. (2019). Kriteria Pembatasan Hak Cipta Lagu Dalam Praktik Covering M elalui Youtube. JIPRO. 2(1): 28.
} 
books. The data were analyzed qualitatively through data classification, data editing, and narration.

\section{FINDINGS AND DISCUSSION}

\section{The Right of Recall in a Democratic Country}

Democracy is identified as people's sovereignty, ${ }^{10}$ which means that the government originates from the people, is carried out by the people, and for the welfare of the people.

A characteristic of democracy is free election, which Huntington calls as a minimal definition of democracy. In a representative system, democracy also demands on accountability from representatives. In a more essential context, according to Amartya Sen, democracy demands an opportunity for all parties, which includes opportunities for people to participate in all political processes like in the selection process or the dismissal of the House of Representatives or Assembly at Provincial.

Prezeworski et al define democracy as a regime that has elections to fill government positions. ${ }^{11}$ Schumpetarian has another perspective on democracy, that is democracy as a political method that dominates the theory of democracy, so an election is the most important element of a democratic country.

In this modern era, elections are important because they are related to several things: First, elections are a mechanism for the continuity of pure democracy. Second, elections are an

${ }^{10}$ Abdy Yuhana, Sistem Ketatanegaraan Indonesia Pasca Perubahan UUD 1945, Fokusmedia, Bandung, 2009, p. 34.

${ }^{11}$ Developing Democracy: Toward Consolidation, Larry Diamond, 1999, dikutip dari Sigit Pamungkas, Perihal Pemilu, Yogyakarta, Laboratorium Jurusan Ilmu Pemerintahan dan Jurusan Ilmu Pemerintahan Universitas Gadjah Mada, 2009, p. 3. indicator of a democratic country. In fact, there is no country that claims to be democratic without holding elections, even though that country is an authoritarian country. ${ }^{12}$

According to Mukhti Fadjar, the legal policy regarding the right of recall is strongly influenced by political will, supra political structure (government and House of Representatives), and infra structure of politics (political parties) themselves which are not always appropriate to the concept of people's sovereignty and the belief of House of Representatives as the representation of the people, not the party's itself. ${ }^{13}$ Recalling by political parties for their members sitting in representatives on the grounds of violation of country's articles of association, as in Article 12 letter b of the Political Party Law, does not guarantee the principle of due process of law, because it can be leader's subjective decision that are difficult to control by the public. ${ }^{14}$

Moh. Hatta also stated that:

The right of recall was a contrary to democracy especially to democracy of Pancasila. Party leader had no right to eliminate his elected members. Apparently, in reality, the party leader felt more powerful than his constituents. If so, he suggested that the election be eliminated. Basically the right of recall was dismissed due to this recall right only existed in communist and fascist countries. ${ }^{15}$

12 Gelombang Demokratisasi Ketiga, Samuel P. Huntington, Graviti, Jakarta Pusat, 1995, in Sigit Pamungkas, Perihal Pemilu, Yogyakarta, Laboratorium Jurusan Ilmu Pemerintahan dan Jurusan Ilmu Pemerintahan Universitas Gadjah Mada, 2009, p. 3.

13 Ni'matul Huda, "Recall Anggota DPR dan DPRD dalam Dinamika Ketatanegaraan Indonesia", Mimbar Hukum, Volume 23(3), 2011, pp. 460-461.

14 The Judgments of Constitutional Court RI No. 008/PUU-IV/2006

15 Deliar Noer, Mohammad Hatta Suatu Biografi Politik, LP3ES, Jakarta, 1989, pp. 305306. 
As for Moh. Mahfud MD., interpreted recalling as the right to replace the consultative or representative members from their positions, so that they had membership status no more in the institution. ${ }^{16}$ Using the right of recall, the House of Representatives and Assembly of Provincial members in parliamentary can be deprived from their status and replaced by others. However, It becomes irrelevant when the political party's recall right is allowed to grow and develop in it because the existence of this right of recall is a betrayal of the legitimacy given by the people to the House of Representatives or Assembly of Provincial.

\section{The Implementations of Parties's Right of Recall in Indonesia}

In a democratic country, political parties must not only have to exist, but also must have strong social legitimacy. Political parties must be a place to accommodate the aspirations of the people because the modern democratic system is based on the system of representatives. ${ }^{17}$ Through the amendment of the 1945 Constitution, the social, political and legal sectors in Indonesia have been changed. The change has implications on the development of democracy in Indonesia, which is marked by direct elections to elect the president, vice president and legislative members. ${ }^{18}$

In Indonesia's governing administration, recalling has been existed and is known formally since the new order came to power through Law Number 10 of 1966 which regulated the position of the Temporary People's Consultative Assembly and People's Representative Council of Mutual Assistance. This law

16 Moh. Mahfud MD, Perkembangan Politik Hukum, Studi tentang Pengaruh Konfigurasi Politik. terbadap Produk Hukum di Indonesia, Dissertation, Doctoral Program of Law Faculty at UGM, Yogyakarta, 1993, p. 325.

17 Firman Subagyo, Menata Partai Politik dalam Arus Demokratisasi Indonesia, Wahana Semesta Intermedia, Jakarta, 2008, p.6.

18 Rida Farida, Op.Cit., h. 196. was born a few months after the new order rose to the political stage to replace the old order. The inclusion of recall right in Law Number 10 of 1966 was in the context to clean up loyal People's Representative Council of Mutual Assistance during the old order ${ }^{19}$ From the historical view, the existence of the recall right of political parties has been used as a tool to expand the parties' power.

Based on Article 15 of Law Number 10 of 1966 concerning the Position of the Temporary People's Consultative Assembly and People's Representative Council of Mutual Assistance towards the general election, one of the reasons that can be used to replace their members was by the request of the parties where the members belong. Furthermore, in the reformation, recalling by political parties was no longer held as one of the reasons for the dismissal of members in parliament. However, in 2003, the right to recall resurfaced through Law Number 22 of 2003 concerning the Composition and Position of the People's Consultative Assembly, House of Representatives, Regional Representatives Council, and Provincial Assembly. In article 85 paragraph (1) letter "a" affirmed that members of the House of Representatives could stop due to a proposal by the related political party.

The recall process is started from a letter submitted by the proposing party to the leader of the House of Representatives. Next, the leader will continue the letter to the General Elections Commision to be followed up to the President and notify the leader of House of Representatives. Then, the President issues a Presidential Decree and returns it to the General Elections Commision. The Presidential Decree was then submitted to the leader of the House

19 Bintan R. Saragih, Peranan DPR-GR Periode 1965-1971 dalam Menegakekan Kebidupan Ketatanegaraan yang Konstitusional Berdasarkan UUD 1945, Dissertation, Law Faculty of Padjajaran University, Bandung, 1992, p. 323. 
of Representatives. Finally, the replacement of the party cadres will be conducted.

The recall right phenomena reemerged after the legalization of Law No. 22 of 2003. The phenomena included Marissa Haque, Djoko Edhi Sutjipto Abdurrahman, and Dharmono K Lawi. Marissa Haque and Dharmono $\mathrm{K}$ Lawi were members of the House of Representatives from PDIP. In 2006, PDIP recalled Dharmono $K$ Lawi for being a suspect in a corruption case for housing funds and assistance funds for Banten Provincial Assembly activities. Marissa Haque was recalled by PDIP because she was officially nominated by Partai Keadilan Sejabtera to become the deputy governor of Banten for 20072012.20

$$
\text { Djoko Edhi Sutjipto }
$$
Abdurrahman was a member of Indonesian Parliament in 2004 to 2009 from Partai Amanat Nasional (PAN). Djoko Edhi was recalled by PAN because of his benchmarking study about Gambling law in Egypt was considered to be in conflict with PAN's articles of association. As a result, Djoko Edhi submitted a constitutional review of article 85 paragraph (1) letter "c" and article 12 letter "b" which stated that "The House of Representatives Members stop intermittently because: c. proposed by the political party"21. One reason for the request was that the existence of recall right was immeasurable and subjective which violated the principles of democracy and legal certainty. ${ }^{22}$

20 Bambang, "Kejagung Umumkan Buronan Koruptor Dharmono K. Lawi”, https://www.antaranews.com/berita/48498/kejagu ng-umumkan-buronan-koruptor-dharmono-k-lawi, December 11th 2006, accessed on July 24th 2019.

${ }^{21}$ Priyambodo RH, "MK Tolak Permohonan Djoko Edhi", https://www.antaranews.com/berita/43276/mktolak-permohonan-djoko-edhi, September 28th 2006, accessed on July 25th 2019.

22 Judgements of Constitutional Court No. 008/PUU-IV/2006, pp. 11-12.
The Constitutional Court rejected the petition. The Court stated that the right of recall given to members of political parties who had deviated from party policy was normal because if a person had been in the party he must also accept any sanction given to $\mathrm{him}^{23}$. However, as a react to the decision, there were several dissenting opinions from Abdul Mukhtie Fadjar, Maruarar Siahaan, Jimly Asshidiqie, and Laica Marzuki.

Judge Abdul Mukhtie Fadjar stated in his dissenting opinion that the implementation of recall did not guarantee the implementation of due process of law. ${ }^{24}$ Meanwhile, Jimly Asshidiqie and Maruarar Siahaan stated that although the relationship between a candidate and a political party was in private law, when the candidate had officially become a member of the House of Representatives, the relationship had shifted to public law that should be emphasized to constituents who had elected the member. ${ }^{25}$ Moreover, Judge Laica Marzuki stated that as a consequence of adopting an open proportional system, political parties should not be able to do a recall, because it ignored the citizens' legitimacy to elect the members. ${ }^{26}$

Furthermore, according to recent law, article 239 paragraph (2) of number 17 of 2014 concerning the People's Consultative Assembly, House of Representatives, Regional Representatives Council, and Provincial Assembly (MD3 Law), the House of Representatives members may be dismissed through a proposal from its political party based on statutory provisions. The dismissal of the Provincial Assembly is regulated in article 355 paragraph (2) of MD3 Law. The method for dismissing is through a proposal from its political party as regulated in article 405 paragraph (2) of MD3 Law.

$$
\begin{aligned}
& { }^{23} \text { Ibid, } p 61 . \\
& { }^{24} \text { Ibid, } p 63 . \\
& { }^{25} \text { Ibid, } p 68 . \\
& { }^{26} \text { Ibid, } p 76 .
\end{aligned}
$$


The existence of this regulation causes problems, because a Provincial Assembly member sits as a member of parliament with legitimacy from the people's votes, and not from the votes of political parties. $^{27}$ Although a political party is an important element in the dynamics of Indonesian goverment administration ${ }^{28}$, Indonesian adopts a separation of power with checks and balances principle. Concequently, it is also necessary to have a limitation on the power of political parties, especially political parties that hold the highest leadership, both in the legislative and executive domains. ${ }^{29}$

A political party's right of recall has a potential to shift the people sovereignty into political parties sovereignty even if in the 1945 Constitution of the Republic of Indonesia states that sovereignty is in the hands of the people and implemented according to the constitution. This right of recall is an action that excludes the legitimacy of the people who have been transferred to members of the House of Representatives or Provincial Assembly through elections.

\section{CONCLUSION}

According to the concept of democracy, the election of the House of Representatives and Assembly at Provincial are carried out by the citizen. It becomes irrelevant if the party's right of recall is allowed to grow and develop in it. Because the existence of this right of recall is actually an opposite of the legitimacy given by the citizen to members of the the House of Representatives and Assembly at Provincial. In Indonesia, the recall right of political parties has been existed and is known since the new order came in 1966. Nowadays, the party's right of recall is still implemented through the MD3 Law.

27 Rumokoy, Nike K. 2018. Kajian Yuridis Tentang Hak Recall Partai Politik dalam Sistem Ketatanegaraan Indonesia. Jurnal Magister Hukum Udayana. Volume 20(1), p. 1.

$$
{ }^{28} \text { Ibid. }
$$

\section{SUGGESTION}

There should be a number of considerations in dismissing the members from the House of Representatives. First, the dismissal process in an internal party must be carried out based on due process of law. Second, the due process of law is also used for dismissing the members of House of Represenatives Thus, the dismissal of a political party members is not merely a unilateral decision of a political party, but also based on a due process mechanism of law.

\section{REFERENCES}

\section{Laws and Regulations}

The Constitution of the Republic of Indonesia of 1945

Law of the Republic of Indonesia No. 10 of 1966

Law of the Republic of Indonesia No. 22 of 2003

Law of the Republic of Indonesia No. 27 of 2009

Law of the Republic of Indonesia No. 17 of 2014

The Judgments of Constitutional Court of Republic Indonesia No. 008/PUUIV/2006

\section{Books}

Asshiddiqie, Jimly. 2007. Pokok-Pokok Hukum Tata Negara Indonesia Pasca Reformasi. Jakarta: BIP.

Budiardjo, Miriam. 1992. Dasar-Dasar Ilmu Politik. Cet. XIV. Jakarta: Gramedia Pustaka Utama.

Marijan, Kacung. 2010. Sistem Politik Indonesia: Konsolidasi Demokrasi Pasca-Orde Baru. Jakarta: Kencana.

Noer, Deliar. 1989. Mohammad Hatta Suatu Biografi Politik, Jakarta: LP3ES.

Pamungkas, Sigit. 2009. Perihal Pemilu, Yogyakarta: Laboratorium Jurusan Ilmu Pemerintahan dan Jurusan Ilmu Pemerintahan Universitas Gadjah Mada.

Salang, Sebastian. 2007. Potret Partai Politik di Indonesia. Jakarta: Forum Politisi. 
Subagyo, Firman. 2008. Menata Partai Politik dalam Arus Demokratisasi Indonesia. Jakarta: Wahana Semesta Intermedia.

Yuhana, Abdy. 2009. Sistem Ketatanegaraan Indonesia Pasca Perubahan UUD 1945. Bandung: Fokusmedia.

\section{Dissertation}

MD, Moh. Mahfud. 1993. Dissertation. Perkembangan Politike Hukum, Studi tentang Pengaruh Konfigurasi Politik terhadap Produk Hukum di Indonesia, Yogyakarta: Doctoral Program of UGM Law Faculty, Yogyakarta.

Saragih, Bintan R. 1992. Dissertation. Peranan DPR-GR Periode 1965-1971 dalam Menegakean Kehidupan Ketatanegaraan yang Konstitusional Berdasarkan UUD 1945, Bandung: Law Faculty of Padjajaran University.

\section{Journal's Articles}

Farida, Rida. 2013. Mekanisme Penggantian Antar Waktu (PAW) Anggota DPR dan Implikasinya dalam Konsep Perwakilan Rakyat. Jurnal Cita Hukum. Volume I (2).

Huda, Ni'matul. 2011. Recall Anggota DPR dan DPRD dalam Dinamika Ketatanegaraan Indonesia. Mimbar Hukum. Volume 23(3).

Rumokoy, Nike K. 2018. Kajian Yuridis Tentang Hak Recall Partai Politik dalam Sistem Ketatanegaraan Indonesia. Jurnal Magister Hukum Udayana. Volume 20(1).

\section{Websites}

Aru. Januari 22nd 2007. Mempertanyakan Hegemoni Recall Anggota DPR di Tangan Partai Politik. https://www.hukumonline.com/berita /baca/hol16071/mempertanyakanhegemoni-irecalli-anggota-dpr-ditangan-partai-politik. Accessed on July 25th 2019.

Bambang. December 11th 2006. Kejagung Umumkan Buronan Koruptor Dharmono K. Lawi. https://www.antaranews.com/berita/ 48498/kejagung-umumkan-buronankoruptor-dharmono-k-lawi. Accessed on July 24th 2019.

Prawisasra, Inka dan Noviar Jamal. Agust 30th 2006. Marissa Haque Dicoret dari Fraksi PDIP.

https://www.liputan6.com/news/read /128246/marissa-haque-dicoret-darifraksi-

pdip?related $=$ dable\&utm_expid $=.9 Z 4 \mathrm{i}$ 5ypGQeGiS7w9arwTvQ.1\&utm_refer rer $=$ https $\% 3 \mathrm{~A} \% 2 \mathrm{~F} \% 2 \mathrm{Fwww}$. google.c om $\% 2 F$. Accessed on July 24th 2019.

RH, Priyambodo. September 28th 2006. MK Tolak Permohonan Djoko Edhi. https://www.antaranews.com/berita/ 43276/mk-tolak-permohonan-djokoedhi. Accessed on July 252019. 
158 | Shevierra Danmadiyah dkk., A Partys Recall, hlm.151-158 